\title{
Timing of pedagogical intervention: Oral error treatment in EFL vs. CLIL contexts in primary education in Spain
}

\author{
José Luis Estrada $^{a *}$, Ana Otto ${ }^{b}$ \\ ${ }^{a}$ University of Cádiz, Faculty of Education, Puerto Real 11519, Spain \\ ${ }^{b}$ Madrid Open University (UDIMA), Department of Language Education, Collado Villalba 28400, Spain \\ APA Citation:
}

Estrada, J. L.., \& Otto, A. (2019). Timing of pedagogical intervention: Oral error treatment in EFL vs. CLIL contexts in primary education in Spain. Journal of Language and Linguistic Studies, 15(2), 578-586.

Submission Date:12/11/2018

Acceptance Date:07/02/2019

\begin{abstract}
This study stresses the major circumstances in terms of timing of pedagogical intervention in English as a Foreign Language (EFL) and Content Language Integrated Learning (CLIL) contexts within the same school setting in Madrid (Spain). The rationale of the research lies in the EFL and CLIL Primary Education teachers' preferences for online and offline correction (Pawlak, 2014). In order to gather significant data, classroom observation took place to list teachers' timing of error correction in oral communication -i.e., whether EFL and CLIL teachers perform immediate, delayed, or postponed correction. As for content and language integration, recent literature (Coyle, 2010; Wewer, 2017) stands out that CLIL practice should reflect upon alternative teaching methods different to EFL instruction (i.e. focus on language forms). Contrary to the expectations, the results highlight that there are no major differences of the timing of pedagogical intervention between EFL and CLIL teachers: Mostly all oral errors committed during EFL and CLIL courses were immediately intervened. In light of the results, some recommendations are proposed concerning the focus on language functions; i.e., being able to develop communicative competence and collaborative work along with language teachers.
\end{abstract}

(C) 2019 JLLS and the Authors - Published by JLLS.

Keywords: English as a Foreign Language (EFL); error treatment; Content and Language Integrated Learning (CLIL); primary education; timing of pedagogical intervention.

\section{Introduction}

Error treatment has historically been considered inherent to language pedagogy. For that reason, it has also been one of the most recurrent research topics in terms of foreign language (henceforth FL) teaching, mainly due to Corder's $(1967 ; 1981)$ work. How to tackle language errors in the most precise way -in terms of FL acquisition- is still a significant teaching issue, even though most teachers do consider error treatment (i.e., error correction) as an essential teaching duty. Therefore, FL teachers feel responsible for providing accurate corrective feedback (henceforth CF) in case an error is committed in both written and oral communication. For carrying this out, FL teachers might reflect upon what Pawlak (2014) describes as an offline and online correction; i.e., if pedagogical intervention is postponed or not.

\footnotetext{
${ }^{*}$ Corresponding author. Tel.: +34-956-016-251

E-mail address: joseluis.estrada@uca.es
} 
If error treatment takes place during oral communication, it can be either immediate, delayed, or postponed; in the case, it aims at written communication, intervention is usually postponed.

Timing of pedagogical intervention seems to be an extremely challenging task for FL teachers, even though immediate correction is the choice used more frequently and preferred by students and teachers (Park, 2010 -referring to the US context). FL teaching should differ from current practices such as bilingual education, being the Content and Language Integrated Learning (henceforth CLIL) approach the most widespread in Europe since the 1990s. More particularly, CLIL is a dual-focused approach in which an additional language is used for the learning as well as teaching of both content as well as language (Coyle, Hood \& Marsh, 2010). Therefore, FL instruction does not seem to be arranged in the same manner than CLIL teaching (Moore, 2009) does; e.g., it possibly implies an alternative approach to the timing of pedagogical intervention.

This work compares then two contexts of English as FL (henceforth EFL) and CLIL in the same school setting in Madrid (Spain) concerning the timing of pedagogical intervention. The main objective is to analyze the data gathered in Primary Education through classroom observation to make sure different timing of error treatment is performed depending on whether teachers cope with EFL or CLIL students. Finally, the discussion will lead the readers into a list of tips on FL issues in CLIL subjects concerning the timing of error treatment to make language acquisition more effective.

\subsection{Literature review}

Error treatment is still a paramount challenge in FL teaching (Pawlak, 2015). For teachers, it implies treating errors given two factors: $\mathrm{CF}$ techniques and timing. First, error-correction techniques largely depend upon the different varieties of CF (Lyster \& Ranta, 1997): recast; explicit correction; clarification request; metalinguistic feedback; elicitation; and repetition. However, it is also worth stressing Truscott's $(1996 ; 1999)$ position against error correction to the point that "grammar correction should be abandoned." (p. 360) Second, the timing of pedagogical intervention can be categorized into online and offline correction (Pawlak, 2014) depending on whether it concentrates on errors taking place in written or oral communication. As for the former, the timing of error treatment is divided as follows: Immediate correction, delayed correction, and postponed correction (Allwright \& Bailey, 1991).

These types of pedagogical intervention have historically and exclusively been analyzed within FL teaching in connection with accuracy-based activities or fluency-oriented tasks. On the one hand, accuracy-based activities usually imply immediate teacher correction to make the learner aware of his/her error at the very moment he/she makes it. In terms of fluency-oriented tasks, the timing of pedagogical intervention does take into consideration three options (immediate, delayed, or postponed correction) concerning un/focused communication tasks. Pawlak (2014) sums up this situation as follows: "it would appear that the selection of one of these three options primarily depends upon the nature of the instructional activity in hand at a particular point of a lesson." (p. 118)

In the case of oral error treatment, it has to be considered whether the school subjects are strictly linguistic (mainly EFL) or not (all remaining CLIL subjects apart from Mathematics and Language which are taught through EFL: Physical Education, Arts, and Crafts, Social Science, Social Studies, etc.). The CLIL approach, for example, involves the integration of content and language, which apparently needs a readjustment of teaching methodologies from several angles: One of those new perspectives has to do with techniques in which oral error treatment is applied to classroom activities (Milla-Melero, 2016). Due to the very nature of the CLIL approach, it should assist the development of learners' thinking abilities too: CLIL students should move from remembering and understanding to applying, analyzing, evaluating and creating knowledge. 
The rationale behind the CLIL approach implies a methodological adaptation to the standards of bilingual education (Coyle, 2008), bearing in mind that teachers are expected to be specialists in nonlinguistic fields of knowledge but not frequently experts on CLIL, at least in Spain (Cabezuelo-Gutiérrez \& Fernández-Fernández, 2014; Halbach, 2010; Olivares-Leyva \& Pena-Díaz, 2013; Pavón, \& Ellison; 2013; Salaberri-Ramiro, 2010). In this sense, Wewer (2017: 279) points out the following: "due to the content-driven dual focus, it is logical that content teacher, at least in non-Anglophone settings (see Coyle, 2013), are the ones teaching through English-with varying linguistic, educational backgrounds ranging from no language studies to double qualifications in both content and language (Nikula \& Järvinen, 2013; see also Hüttner \& Smit, 2014)." However, current research on oral error treatment in FL and CLIL instruction (Estrada, 2017) exposes the deficiencies and lack of understanding for methodological adaptations in CLIL contexts.

\subsection{Research questions}

The present study aims at examining the timing of pedagogical intervention in EFL and CLIL contexts in a primary education school in Madrid (Spain) concerning oral error treatment. Bearing this in mind, the research questions are as follows:

1. What are the most frequent error correction techniques among teachers in the EFL/CLIL contexts of analysis?

2. What are the most important similarities and differences between EFL and CLIL teachers' practices in relation to timing of pedagogical intervention?

\section{Method}

The objective of this research is to identify similarities and differences between EFL and CLIL teaching practices about the timing of pedagogical intervention: immediate, delayed, and postponed correction. Carrying this research out will make it possible to conclude whether EFL and CLIL teachers adapt themselves to each approach in the context of analysis.

\subsection{Data collection procedures}

The research methodology focuses on the observation of 28 sessions in Primary Education (henceforth PE) in a private school in Madrid (Spain) among Years 1-6. PE is split into three stages in Spain: Stage 1 (Years 1 and 2); Stage 2 (Years 3 and 4); and Stage 3 (Years 5 and 6). Classroom observation took place in both EFL $(n=19)$ and CLIL courses (Social Science and Social Studies; $n=9$ ) with a total number of 15-25 students/classroom. Finally, there were seven teachers (five EFL teachers and two CLIL teachers). All teachers were native Spanish speakers except for one whose native tongue was Greek. He had to certify a $\mathrm{C} 1$ level according to the Common European Framework of Reference (Council of Europe, 2001).

The observation of EFL and CLIL sessions did not mean taking part in classroom activities in order to avoid interceding in the normal development of teaching dynamics. Because of the impossibility of video and audio recording the EFL and CLIL sessions, oral errors were written down by using a computer spreadsheet (i.e., MS Office -Excel software). Additionally, all oral errors that were not apparently treated were also considered for research purposes. 


\section{Results}

The final amount of oral errors was 147 after attending 28 sessions (5.25 errors/session). Overall, six errors $(4.08 \%)$ were not treated. During the $19 \mathrm{EFL}$ sessions observed, the numbers of errors were 116 (6.10 errors/session), in which five errors (4.31\%) were not CF-treated. Moreover, 30 errors were made during the observation of nine CLIL sessions (3.33 errors/session). In this case, only two errors (6.45\%) were not CF-treated.

For the purpose of this study, the main results show that EFL and CLIL teachers feel responsible for the intervention upon oral errors (95.91\%); i.e., they interrupt the learners once they make an error. Moreover, EFL and CLIL teachers prefer to do it immediately (87.25\%). The analysis of the data gathered in relation to the timing of pedagogical intervention remains almost the same for EFL (85.58\%) and CLIL subjects $(90.32 \%)$ as regards immediateness. It is worth emphasizing the almost complete lack of postponed error corrections $(n=1 ; 0.68 \%)$ during EFL and CLIL sessions. Table 1 offers specific information about the timing of pedagogical information in EFL and CLIL instruction:

Table 1. Timing of pedagogical intervention: EFL and CLIL

\begin{tabular}{llll}
\hline EFL & & & \\
\hline Immediate & Delayed & Postponed & Non-CFed \\
$95(85.58 \%)$ & $16(14.41 \%)$ & $0(0.00 \%)$ & $5(4.31 \%)$ \\
\hline CLIL & & & \\
\hline Immediate & Delayed & Postponed & Non-CFed \\
$28(90.32 \%)$ & $1(3.22 \%)$ & $1(3.22 \%)$ & $1(3.22 \%)$ \\
\hline
\end{tabular}

Furthermore, Table 2 specifies the number of sessions observed in PE by stages, the timing of pedagogical intervention (immediate, delayed, and postponed), and the amount of non-CF-treated errors. It is also relevant to highlight the fact that no one single CLIL session was observed in Stage 2 due to time (i.e., teaching hours) inconsistencies (during the time allocated for data collection, SeptemberDecember 2015, the lead author was also working as Secondary Education teacher in the same school where the research was conducted. For this reason, Stage 2 CLIL sessions could not be observed):

Table 2. Timing of pedagogical intervention by stages

\begin{tabular}{lllll}
\hline EFL & & & \\
\hline & Immediate & Delayed & Postponed & Non-CFed \\
S1 $(\mathrm{n}=6)$ & $10(76.92 \%)$ & $2(15.38 \%)$ & $0(0.00 \%)$ & $1(7.69 \%)$ \\
S2 $(\mathrm{n}=6)$ & $50(81.97 \%)$ & $8(13.11 \%)$ & $0(0.00 \%)$ & $3(4.92 \%)$ \\
S3 (n=7) & $35(83.33 \%)$ & $6(14.28 \%)$ & $0(0.00 \%)$ & $1(2.38 \%)$ \\
\hline CLIL & & & & \\
\hline & & Delayed & Postponed & Non-CFed \\
S1 (n=6) & $13(86.67 \%)$ & $1(6.67 \%)$ & $0(0.00 \%)$ & $1(6.67 \%)$ \\
S3 (n=3) & $15(93.75 \%)$ & $0(0.00 \%)$ & $0(0.00 \%)$ & $1(6.25 \%)$ \\
\hline
\end{tabular}




\section{Discussion}

In order to answer the two research questions, it is worth stating that the overall results in terms of error treatment and, above all, the timing of pedagogical intervention are consistent across classroom observation. First, the most dominant error correction technique (in EFL and CLIL courses) aims at the use of CF. CLIL teachers (99.77\%) use CF even more frequently than EFL teachers (95.69\%). This situation contradicts previous research on the frequency of L2 use and error correction conducted in PE in Spain (Lorenzo, Casal \& Moore, 2009; Fuentes-Arjona, 2015), in which CLIL teachers only put error correction into practice "sometimes." Moreover, the constant use of CF removes the possibility of EFL and CLIL teachers accepting the lack of pedagogical intervention as an error correction technique per se (Estrada, 2017).

Thus, the question concerning CLIL instruction is: Should all oral errors -taking into consideration the context of analysis (96.78\%)- be corrected? This could reveal irregularities in contrast with relevant research on how to assist teachers in "focusing on substantial areas of CLIL teaching to ensure that the language focus is not too narrow but sufficiently addressed." (Wewer, 2017: 280) The Observation Tool for Effective CLIL Instruction (de Graaff et al., 2007), for example, develops different areas for CLIL teachers to consider concerning FL acquisition: Exposure to input; meaning and form-focused processing; output production; and use of strategies.

Second, the timing of pedagogical intervention mostly takes place at precisely the right time that errors are committed $(87.86 \%)$ in both EFL and CLIL courses. Nonetheless, there is also an essential difference between teachers' preferences: EFL teachers interrupt learners $(85.58 \%)$ less often than CLIL teachers (96.55\%) do. This might differ from what is expected in CLIL instruction (Dalton-Puffer, 2011; Hüttner \& Smit, 2014) and, more specifically, the timing of error correction. Bearing in mind that CLIL is an "umbrella term" covering a dual-focus on meaning (content) and form (language), language is "rather perceived as 'a resource than a system of rules' whereby fluency is rated higher than accuracy (Pérez-Cañado, 2017)." (Wewer, 2017: 279) So, the amount of oral errors that were immediately intervened in the CLIL classroom is opposed to the choice of one specific pedagogical intervention technique depending on whether the activity in hand is fluency-oriented or accuracy-based. In this sense, the results show that the activities carried out were mostly accuracy-based. As a result, "the optimal solution appears to be an immediate correction which would also be explicit (overt) enough for the learner to notice." (Pawlak, 2014: 118)

The observation of CLIL teachers made clear that they identify language as a systematic system and not as a means of communication (Bovellan, 2014). This being said, Moore (2009) identifies six differences between FL and CLIL teaching, considering only the following ones for this research: (i) focus on language (FL) vs. focus on content/meaning (CLIL); and (ii) language learners (FL) vs. language users (CLIL). To what extent do CLIL teachers consider then the distinctions between (i) and (ii) concerning the timing of pedagogical intervention? As Pawlak (2014: 188) points out, immediate correction "is frowned upon by several methodologists (e.g., Edge 1989; Ur 1996; Harmer 2007) and may be dispreferred in classroom discourse (Seedhouse, 2004)." An immediate correction could be disruptive and even discourage students from participating -according to Van Patten (1990), it is not possible for learners to attend to and process simultaneously both language meaning and form-, even though when CLIL instruction is expected to facilitate "a tsunami of input and output." (Ball, personal communication, June 2, 2018). 


\section{Conclusions}

Despite the efforts made concerning bilingual education research to prove that content-language integration does require an approach to language acquisition (Moore, 2009) different to "traditional" FL teaching, this study presents similar behaviors concerning EFL and CLIL teachers' timing of error correction. Thus, the combination of focused and unfocused communication tasks expected in CLIL instruction (Coyle, 2010) should hopefully result in the use of different types of the timing of intervention rather than only immediateness. Since the context of analysis takes place in PE, learners require "plenty of exposure to simple, communicative English during the first years of CLIL study to develop basic BICS skills from which they advance toward more academic CALP" (Wewer, 2017: 281). CLIL (and EFL) learners should be then allowed to make errors and not being immediately interrupted for that. Actually, errors -mainly those taking place in oral language- are a natural part of FL acquisition that cannot be exclusively treated through CF strategies (e.g., recasts and explicit correction, among others.) but through enough exposure to the FL (Crain \& Lillo-Martin, 1999) in terms of quality and quantity (Krashen, 1985).

In order to assist CLIL teachers in dealing best with error treatment with respect to the timing of intervention, some tips are provided below after discussing and reflecting upon the results obtained in PE throughout EFL and CLIL classroom observation across three different educational stages. Therefore, when handling language issues in CLIL subjects, teachers should bear in mind students' limited (E)FL proficiency. Unlike non-bilingual subjects, in which students use their L1 (mother tongue; e.g., Spanish), CLIL students are life-long learners and, as such, the use of an additional language is usually an added difficulty for them, especially at the primary stages of FL learning. Therefore, content teachers should,

- Be responsible for language input and output. They should highlight the specific language, which students will need and try to show it in connection with grammar patterns and functions. They should also focus on language functions rather than language forms.

- Encourage every attempt to communicate on the students' part. They should look for meaning rather than correction and rephrase/paraphrase only when they find it necessary for the message to be understood.

- Gather with the Language (i.e., EFL) Department and find out which language issues are most challenging for students at every stage, and the most common errors they make. This collaboration will provide content teachers a deeper understanding of students' language, and it will help then deal with frequent errors. Some knowledge of the several levels in the Common European Framework of Reference can also be useful to identify which errors need to be noticed and when this may happen, and which others can be overlooked depending on the different learning stages.

\section{References}

Allwright, R. \& Bailey, K. (1991). Focus on the language classroom: An introduction to classroom research for language teachers. Cambridge: Cambridge University Press.

Ball, P. (2018). CLIL: The three dimensions of content, presented at II Congreso Internacional para Profesionales de la Enseñanza Bilingüe, Madrid, Spain. 
Bovellan, E., (2014). Teachers' beliefs about learning and language as reflected in their views of teaching materials for Content and Language Integrated Learning (CLIL) (Ph.D. thesis). University of Jyväskylä, Jyväskylä, Finland.

Cabezuelo-Gutiérrez, P. \& Fernández-Fernández, R. (2014). A case study on teacher training needs in the Madrid Bilingual Project. Latin American Journal of Content and Language Integrated Learning, 7(2), 50-70.

Corder, P. (1967). The significance of learners' errors. International Review of Applied Linguistics, 5, 160-170.

Corder, P. (1981). Error analysis and interlanguage. Oxford: Oxford University Press.

Council of Europe (2001): Common European framework of reference for languages: Learning, teaching, assessment. Cambridge: Cambridge University Press.

Coyle, D. (2008). CLIL-A pedagogical approach. In Van Deusen-Scholl, N. \& Hornberger N. (Eds.) (2008), Encyclopedia of Language and Education (second edition). New York, Springer, 97-111.

Coyle, D. (2010). Classroom Pedagogies for Enhancing CLIL Practice, presented at University of Aberdeen, Aberdeen, Scotland. Retrieved from: https://goo.gl/CFSHK1

Coyle, D. (2013). Listening to Learners: An Investigation into "Successful Learning" across CLIL Contexts. International Journal of Bilingual Education and Bilingualism, 16(3), 244-266.

Coyle, D. Hood, P. \& Marsh, D. (2010). CLIL: Content and Language Integrated Learning. Cambridge: CUP.

Crain, S. \& Lillo-Martin, D. (1999). An Introduction to Linguistic Theory and Language Acquisition. Oxford: Blackwell.

Dalton-Puffer, C. (2011). Content-and-language integrated learning: From practice to principles? Annual Review of Applied Linguistics, 31, 182-204.

de Graaff, R., Koopman, G., Anikina, Y. \& Westhoff, G. (2007). An observation tool for effective L2 pedagogy in Content and Language Integrated Learning (CLIL). The International Journal of Bilingual Education and Bilingualism, 10(5), 603-624.

Edge, J. (1989). Mistakes and Correction. Harlow: Longman.

Estrada, J. L. (2017). Tratamiento de Errores en la Enseñanza de Lenguas Extranjeras en la Educación Superior: Posibilidades de Corrección no Intervencionista en la Producción Oral (Doctoral Thesis). University of Cadiz, Spain.

Fuentes-Arjona, M. (2013). Which score is adequate: Approximation to the assessment rationale used in science through English CLIL written text. Bellaterra Journal of Teaching \& Learning Language \& Literature, 6(4), 54-73. Retrieved from: http://www.raco.cat/index.php/Bellaterra/article/viewFile/297851/386834

Halbach, A. (2010). From the classroom to university and back: Teacher training for CLIL in Spain at the University de Alcalá. In D. Lasagabaster \& P. Ruiz de Zarobe (Eds.), CLIL in Spain: Implementation, Results and Teacher Training. Newcastle upon Tyne: Cambridge Scholars Publishing, 243-256.

Harmer, J, (2007). The Practice of English Language Teaching. Harlow: Pearson Education. 
Hüttner, J. \& Smit, U. (2014). CLIL (Content and Language Integrated Learning): The bigger picture. System, 44, 160-167.

Krashen, S. (1985). The Input Hypothesis: Issues and Implications. London: Longman.

Lorenzo, F. Casal, S. \& Moore, P. (2009). The effects of content and language integrated learning in European education: Key findings from the Andalusian bilingual sections evaluation project. Applied Linguistics, 31(3), 418-442.

Lyster, R. \& Ranta, E. (1977). Corrective feedback and learner uptake: Negotiation of form in communicative classroom. Studies in Second Language Acquisition, 19(1), 37-61.

Milla-Melero, R. (2016). Corrective feedback in oral interaction: A comparison of a CLIL and an EFL classroom (Master's thesis). País Vasco University, Spain

Moore, P. (2009). On the emergence of L2 oracy in bilingual education: A comparative analysis of CLIL and mainstream learner talk (Ph.D. thesis), Pablo de Olavide University, Seville, Spain.

Nikula, T. \& Järvinen, H. (2013). Vieraskielinen opetus Suomessa [instruction in a foreign language in Finland]. In L. Tainio \& H. Harju-Luukkainen (Eds.), Kaksikielinen koulu - tulevaisuuden monikielinen Suomi [Bilingual school—-the multilingual future Finland].

Olivares-Leyva, M. \& Pena-Díaz, C. (2013). How do we train our CLIL teachers? A case study form Alcalá University. Porta Linguarum, 19, 87-99.

Park, H. (2010). Teachers' and learners' preferences for error correction (Master's thesis). California State University, Los Angeles, United States.

Pavón, V. \& Ellison, M. (2013). Examining teachers' roles and competences in Content and Language Integrated Learning (CLIL). Linguarum Arena, 4, 65-78.

Pawlak, M. (2014). Error Correction in the Foreign Language Classroom: Reconsidering the Issues. Heidelberg: Springer-Verlag.

Pawlak, M. (Ed.) (2015). Error Correction in the Foreign Language Classroom: Reconsidering the Issues. Berlin, Heidelberg: Springer-Verlag.

Pérez-Cañado, M. (2017). Stopping the "pendulum effect" in CLIL research: Finding the balance between pollyanna and scrooge. Applied Linguistics Review, 8(1), 79-99.

Salaberri-Ramiro, S. (2010). Teacher training programmes for CLIL in Andalusia. In D. Lasagabaster \& P. Ruiz de Zarobe (Eds.), CLIL in Spain: Implementation, Results and Teacher Training. Newcastle upon Tyne: Cambridge Scholars Publishing, 140-161.

Seedhouse, P. (2004). The Interactional Architecture of the Language Classroom: A Conversation Analysis Perspective. Oxford: Blackwell Publishers.

Truscott, J. (1996). The case against grammar correction in L2 writing correction. Language Learning, 46, 327-369.

Truscott, J. (1999). What's wrong with oral grammar correction. Canadian Modern Language Review, 44(4), 437-456.

Ur, P. (1996). A course in Language Teaching: Practice and Theory. Cambridge: Cambridge University Press.

Van Patten, B. (1990). Attending to form and content in the input. Studies in Second Language Acquisition, 12(3), 287-301. 
Wewer, T. (2017). An observation tool for comprehensive pedagogy in Content and Language Integrated Learning (CLIL): Examples from Primary Education. Colombian Applied Linguistics Journal, 19(2), 277-292.

\section{Pedagojik müdahalenin zamanlaması: İspanya'da ilköğretimde EFL'e karşı CLL bağlamında sözlü hata iyileştirmesi}

\section{$\ddot{O ̈ z}$}

Bu çalışma, Yabancı Dil Olarak İngilizce (English as a Foreign Language: EFL) ve Dil ve İçeriğin Bütünleşik Olduğu Öğrenim (Content Language Integrated Learning: CLIL) kapsamında, pedagojik müdahalenin zamanlaması alanında Madrid'de (İspanya) aynı okul ortamında elde edilen ana sonuçları ortaya koymaktadır. Bu araştırmanın temelini EFL ve CLIL İlköğretim öğretmenlerinin çevrimiçi ve çevrimdışı düzeltme tercihleri oluşturmaktadır (Pawlak, 2014). Kayda değer veriler toplamak amacıyla, öğretmenlerin sözlü iletişimde hata düzeltme zamanlamalarını incelemek, yani EFL ve CLIL öğretmenlerinin düzeltmelerini anında, gecikmeli veya ertelenmiş olarak yapıp yapmadıklarını listelemek için sınıf gözlemi yapılmıştır. İçerik ve dil entegrasyonu ile ilgili olarak, güncel yayınlar (Coyle, 2010; Wewer, 2017), CLIL uygulamalarının EFL eğitiminden farklı alternatif öğretim yöntemlerini yansıtması (yani dil formlarına odaklanması) gerektiğini vurgulamaktadır. Beklenenin aksine, sonuçlar EFL ve CLIL öğretmenleri arasında pedagojik müdahale zamanlamasında önemli bir fark olmadığının altını çizmektedir: EFL ve CLIL dersleri esnasında yapılan sözlü hataların neredeyse tamamına anında müdahale edilmiştir. Sonuçlar ışığında, lisan fonksiyonlarına odaklanmayla ilgili bazı önerilerde bulunulmuş, diğer bir deyişle dil öğretmenleriyle birlikte iletişimsel yeterlilik ve işbirlikçi çalışmalar geliştirebilme olanakları üzerinde durulmuştur.

Anahtar sözcükler: yabanc1 dil olarak İngilizce; hata düzeltme; dil ve içeriğin bütünleşik olduğu öğrenim; ilköğretim; pedagojik müdahale zamanlaması

\section{AUTHOR BIODATA}

Dr. José Luis Estrada is a professor in the Department of Language and Literature Didactics at the University of Cádiz, Spain. His main research interests are language teaching, bilingual education and teacher training.

Dr. Ana Otto is a professor in the Department of Language Education of the Madrid Open University (UDIMA), Spain. Her main research interests are didactics of foreign languages, assessment and CLIL. 